\title{
Recombinant Expression, Isotope Labeling, and Purification of Cold Shock Protein from Colwellia psychrerythraea for NMR Study
}

\author{
Chang-Hun Moon, Ki-Woong Jeong, Hak Jun Kim, ${ }^{+}$Yong-Seok Heo, $\stackrel{+}{\mp}$ and Yangmee Kim ${ }^{-}$
}

\author{
Department of Bioscience and Biotechnologv, Konkuk University, Seoul 143-701, Korea. 'E-mail: whkimíkonkuk ackr \\ ${ }^{\dagger}$ Korea Polar Research Institute, Incheon t06-840, Korea \\ ${ }^{\ddagger}$ Department of Chemistry, Konkuk Chiversitv, Seoul 143-701. Korea \\ Received September 5, 2009, Accepted September 14, 2009
}

\begin{abstract}
Cold shock proteins (Csps) are a subgroup of the cold-induced proteins on reduction of the growth temperature below the physiological temperature. They preferentially bind to single-stranded nucleic acids to translational regulation via RNA chaperoning. Csp plays inportant role in cold adaptations for the psychrophilic microorganism. Recently, Cold shock protein from psychrophilic bacteria, Cohvelia psychrerylwaea (CpCsp) has been identified. Three dimensional structures of a number of Csps from various microorganisms have been solved by NMR spectroscopy or X-ray crystallography, but structures of psychrophilic Csps were not studied yet. Therefore, cloning and purification protocols for further structural study of psychrophilic Csp have been optimized in this study. CpCsp was expressed in E. coll with $\mathrm{pET}-1$ l a vector system and purified by ion exchange, size exclusion, and reverse phase chromatography. Expression and purification of $\mathrm{CpCsp}$ in M9 minimal media was carried out and ${ }^{15} \mathrm{~N}-\mathrm{pabeled}$ proteins with high purity over $90 \%$ was obtained. Further study will be carried out to investigate the tertiary structure and dymanics of $\mathrm{CPCsp}$.
\end{abstract}

Key Words: Cold shock protein. Cohvellia psychrerthraea. Psychrophile. Overexpression. Purification

\section{Introduction}

All living organisms have ability for the survival from enviromment change, such as cold shock, heat shock and the other stresses. ${ }^{1.2}$ When organism was attacked by dramatical cold stress, nomal protein products are decreased, but some special protein products are dramatically increased until adaptation. This is called cold shock protein (Csp). Csps are divided into two types. Class I and II. Class I Csps are expressed low level at 37 ${ }^{\circ} \mathrm{C}$ and are dramatically expressed after a shift to lower temperature. In contrast, class II Csps are present at a certain level at $37^{\circ} \mathrm{C}$ and after temperature falls. expression is increased a little from their steady-state levels. ${ }^{3}$ These proteins found in a gram-positive negative bacteria and they have a highly homologous identity with each other. ${ }^{-1}$ Molecular mass of Csps is approximately $7.4 \mathrm{kDa}$ and preferentially bind to single-stranded nucleic acids to translational regulation wia RNA chaperoning ${ }^{5.8}$ They are consisting of a $\beta$-barrel structure that includes five antiparallel $\beta$-strands. ${ }^{\prime}$ Cold shock proteins have been found in many bacteria. including hyperthermophilic, thernophilic mesophilic and pșclurophilic species. "The three-dimensional stnictures of a number of bacterial Csps have been solved by NMR and X-ray. ${ }^{12.15}$ In case of Bacillis subtillis Csp. three dimensional structure has been determined in complex with hexathy midine. ${ }^{9,11}$

Colwellia psychrerythraea $3+\mathrm{H}$ is considered as an obligate psychrophile. Gram-negative bacteria. This flagella-containing organism can be found in continually cold marine environuments from arctic antarctic deep oceans. sea water. sea ice. and sediment. ${ }^{16}$ Colwellia psichrervthraea cold shock protein (CpCsp) consists of 68 amino acids and molecular mass is $7.2 \mathrm{kDa}$. It shows sequence identities of $60 \%$ with $E$. coli $\mathrm{Csp}$. When temperature is lowered from $37^{\circ} \mathrm{C}$ to $10^{\circ} \mathrm{C}$. it is expressed much more than at higher temperature. It starts expression at cold shock and slowly decreased after 2 hours later. None of the three dimensional structures of psychrophilic Csp has been studied yet. In this study, we performed cloning. expression. isotope labeling. and purification of $\mathrm{CpCsp}$ for further NMR study.

\section{Methods}

Construction of the CsCsp expression plasmid. The plasnid DNA encoding CpCsp protein was kindly provided by Dr. Hak Jun Kim at Korea Polar Research Institute. To increase the production of CpCsp protein in $E$. coli, we cloned the CpCsp gene into $\mathrm{pET}-\mathrm{lla}(+)$ expression vector containing an IPTG inducible promoter and resistance to ampicillin using $\mathrm{NdeI}$ and $B a m \mathrm{HI}$ restriction enz̧ me sites (Figure $\mathrm{I}$ ). PCR was per-

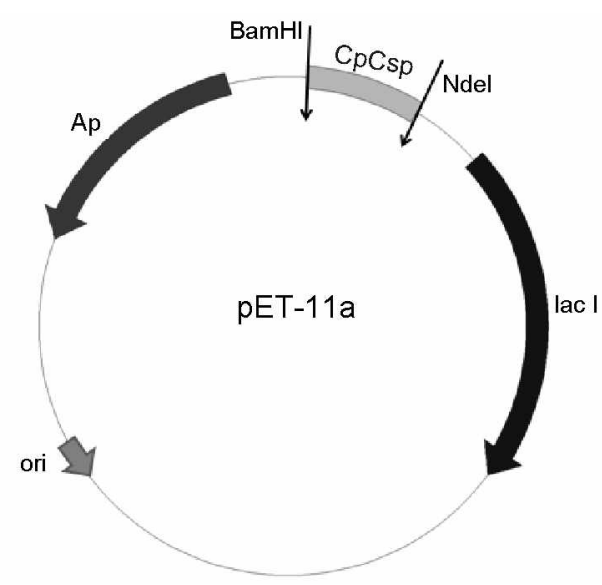

Figure 1. Plasmid map of $\mathrm{CpCsp}$. 

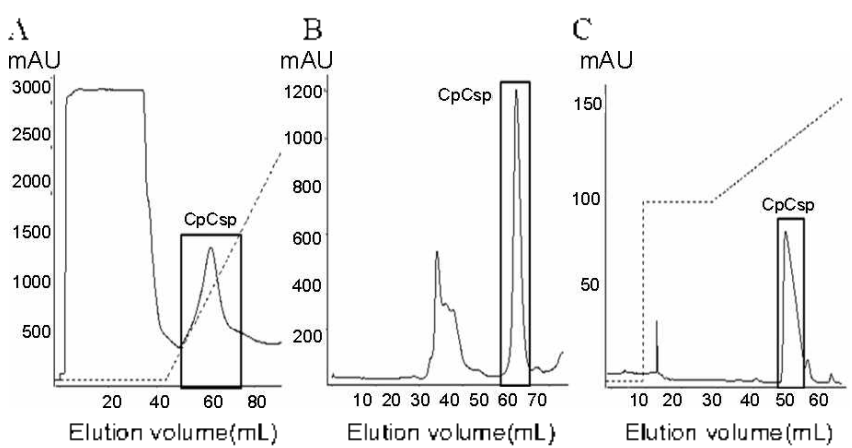

Fingure 2. The elution profile of CpC'sp from ion exchange (A), size vxclusion (B), and hydrophobic interaction chromalography (C). The peak corresponding to CpCsp is marked witl a box. The dotted line denotes the concentration of gradient elution.

formed under the following conditions: 35 cycles of denaturation for $1 \mathrm{~min}$ at $94^{\circ} \mathrm{C}$, anmealing for $1 \mathrm{~min}$ at $55^{\circ} \mathrm{C}$, and extension for $1 \mathrm{~min}$ at $72^{\circ} \mathrm{C}$. The $\mathrm{pE} \mathrm{l}-1 \mathrm{la} / \mathrm{C} p \mathrm{C}$ sp plasmid was translomed into the expression host, E. coli BL2l (DE3) lor expression of C.pCsp. ${ }^{1 ?}$

Expression of CpCsp from an LB medium. Ttansformed cells were grown on Luria-Burtani (LB) agar plates containing $50 \mathrm{\mu g} / \mathrm{mL}$ ampicillin. SDS-PAGE analy sis was used to select a colony lor overexpression of $\mathrm{CpCsp}$. One colony was used to inoculate $50 \mathrm{~mL}$ of LB medium with $50 \mu \mathrm{g} / \mathrm{mL}$ ampicillin, and grown overnight in $377^{\circ} \mathrm{C}$ shaking incubator. $10 \mathrm{~mL}$ of the fully grown culture was mixed with $1 \mathrm{~L}$ of fresh $L B$ medium with 50 $\mu \mathrm{g} / \mathrm{mL}$, and grown al $37^{\circ} \mathrm{C}$ until oplical density reached 0.7 at $600 \mathrm{~nm}$. The culture was induced with $1 \mathrm{mM}$ IPTG and was grown 36 more hours at $10^{\circ} \mathrm{C}$. 'The cells were harvested and the cell pellet was stored at $-80^{\circ} \mathrm{C}$

Expression of $\left[{ }^{15} \mathrm{~N}\right.$-labeled $\mathrm{CpCsp}$ from a minimal medium. One colony was used as an inoculums to $4 \mathrm{mI}$ of $\mathrm{L} . \mathrm{B}$ medium supplemented with $100 \mathrm{hg} / \mathrm{mL}$ and grown ovemight in a $37^{\circ} \mathrm{C}$ shaking incubator. The lully grown $4 \mathrm{~mL}$ culture was used as an inoculum to $100 \mathrm{~mL}$ ol minimal medium supplemented with the same antibiotics, and the culture was grown overnight. The minimal medium contained ${ }^{15} \mathrm{NH}_{4} \mathrm{Cl}$ as a sole nitrogen soutce. the next morning, this $100 \mathrm{~mL}$ culture was mixed with $900 \mathrm{~mL}$ of minimal medium. The culture was grown at $37^{\circ} \mathrm{C}$, and IPTG was added to $1 \mathrm{mM}$ tinal concentration when $O D_{\text {ino }}$ was 1.0. The temperature was switched to $10^{\circ} \mathrm{C}$, and the culture was grown for another 36 hours. The cells were harvested and the cell pellet was stored at $-80^{\circ} \mathrm{C}$. . The cells were resuspended

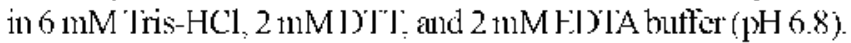

Isolation and purification of $\mathrm{CpCsp}_{\mathrm{P}} \mathrm{All}$ lysis and purilication processes were carried oul al $4{ }^{\circ} \mathrm{C} . \Lambda$ trozen pellet was resuspended and lysed by ultrasonication in buffer $\mathrm{A}(6 \mathrm{mM}$

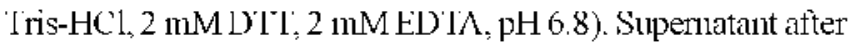
centritugation at $16,000 \mathrm{rpm}$ and 4 " $\mathrm{C}$ was retained for $50 \mathrm{~min}$. The supernatant was loaded onto a Hitrap QF'F' column (anion exchange column, GE) that had been pree(uilibrated with butter A. The column was washed with buffer $B$ and then the bound protein eluted with linear gradient from of to $300 \mathrm{mM} \mathrm{NaCl}$. The CpCsp-containing fraction wete pooled and concentrated by AniconUltra (Millipore). Concentrated C p Csp was purified

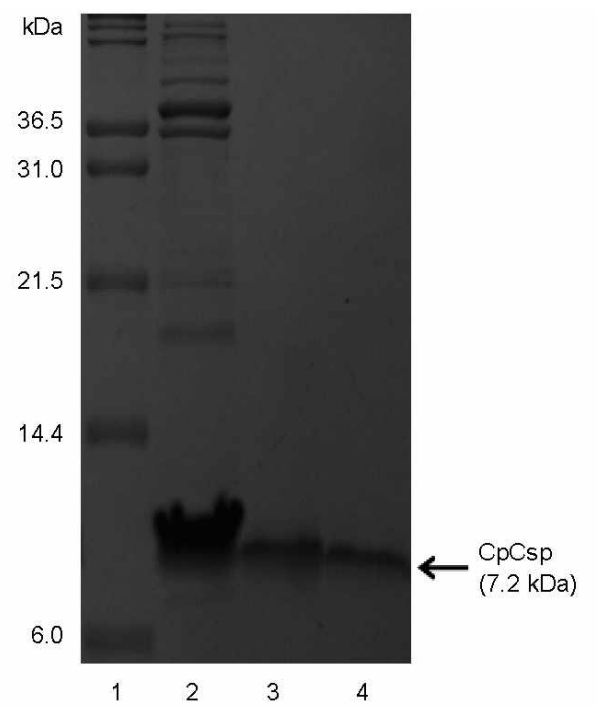

Figune 3. Purification of $\mathrm{CpCsp}$ produced trom $2 \mathrm{I}$ of I B medium as monitored by Tricine SDS-PAGK. lane 1. size marker: lane 2, result of ion exchange chromatography: lane 3 , result of size exclusion chromalography; lane 4, result of hydrophohic interaction chromatography.

using size exclusion chromatography on IliLoad $16 / 60$ Superdex 75 column (Pamasian). Finally, CpCsp-containing fractions were concentrated and purilied by hydrophobic interaction chromalography on Resource RPC (GF). SDS-PACFE analysis was applied to identily $\mathrm{CpC}$ sp-containing fraction.

Circular dichroism. Circular Dichroism (CD) experiments were pertormed by using a J-810 (J $\triangle$ SCO, Tokyo, Japan) spectropolanimeter using with $1 \mathrm{~mm}$ path length cell. The CD spectra of the $\mathrm{CpCsp}(15 \mathrm{mM})$ were recorded at $25^{\circ} \mathrm{C}$ and $0.1 \mathrm{~mm}$ intervals trom 190 to $250 \mathrm{~nm}$ (lar-UV region). For each spectrum, the data trom sis scans were averaged and smoothed CD data were expressed as mean residue ellipticity $[\theta]$ given in deg. $\mathrm{cm}^{2}$ dimol ${ }^{-1}$. ${ }^{18}$

NMR experiments. The NMR sample contained $\left.\left.1 \mathrm{mM}\right|^{1-} \mathrm{N}\right\rceil-$ CpCsp in $50 \mathrm{mM}$ potassium phosphate buller, pII 6.0, containing $5 \mathrm{mM}$ DTT and $0.1 \mathrm{mM}$ Г.DTA. The ${ }^{1} \mathrm{II}_{-}{ }^{15} \mathrm{~N}$ heleronuclear single quantum colnerence (HSQC) spectrum was collected at $25^{\circ} \mathrm{C}$ on a Bruker DMX-400 spectrometer. The raw data acquired with 2,048 data points for $t_{2}$ and 256 for $\mathrm{l}_{1}$ increments. NMR spectrum was processed with the NMRPipe/nmrDraw soliware package and analyzod using the Sparky. ${ }^{19,20}$

\section{Results and Discussion}

Expression of CpCsp from an LB medium. As shown in Figure 3, the purilied CpCsp showed a band corresponding to a molecular mass of $7.2 \mathrm{k}$ Da. To detenmine optimal conditions; we tried several temperatures for cell growth and various $(\mathrm{Ol})_{600}$ values for induction. The optinal temperature and $\mathrm{Ol})_{600}$ were deternined to be $37^{\circ} \mathrm{C}$ and 0.7 , respectively. We further optimized the post-induction growth condition by lowering the temperature to $10^{\circ} \mathrm{C}$.

Expression of $\left[{ }^{15} \mathrm{~N}\right]$-labeled CpCsp from a minimal medium Since the cell growth in minimal media is different from the 


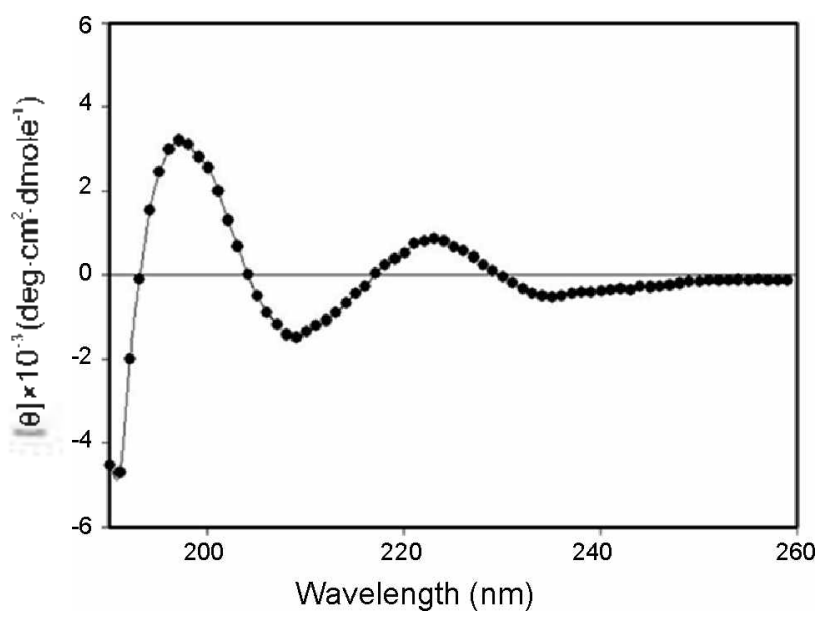

Figure 4. Circular Dichroism spectra of CpCsp in potassium phosphate buffer.

case of LB medium. we tried to find an optimal condition again. In the case of labeled samples. the cells grew only to $70-80 \%$ of what could be expected from the LB medium. We found an optimized temperature of $37^{\circ} \mathrm{C}$ and $1.0 \mathrm{OD}_{\text {exo }}$ value as the best conditions

Purification of CpCsp. Purification of CpCsp consists of three steps. which are ion exchange, size exclusion and hydrophobic interaction chromatography. We followed the general methods reported previously ${ }^{-T}$ but protocols were modified and optimized for CpCsp. Ion exchange chromatography was used by Hitrap QFF column (anion exchange column). CpCsp was eluted with gradient from 5 to 30 percent of B buffer concentration by $\mathrm{NaCl}$. These fractions include many different kinds of impurities. Therefore, each fraction was concentrated by AmiconUltra (Millipore) and concentrated CpCsp was purified using size exclusion chromatography on HiLoad 16/60 Superdex 75 column (Pammasian). Most impurities are detached at this step. but the purity was not enough for the NMR stidy. CpCsp-containing fractions were concentrated and finally purified by hydrophobic interaction chromatography on Resource $\mathrm{RPC}$ column. The CpCsp fraction was collected and lyophilized. The yield of the CpCsp was about $1.5 \mathrm{mg} / \mathrm{L}$ in LB or $1.0 \mathrm{mg} / \mathrm{L}$ in minimal medium. respectively. Purified CpCsp showed a band corresponding to a molecular mass of $7.2 \mathrm{kDa}$. Presence of Ser after methionine at the N-terminus allows the removal of methionine by methionine aminopeptidase.

Cincular dichroism. The $\mathrm{CD}$ spectrum of $\mathrm{CpCsp}$ is given in Figure 4. This spectnum is somewhat unusual. however similar spectra have been observed for CspBs from Bacillus subtilis, ${ }^{23}$ Thermotoga maritime. ${ }^{\lambda-4}$ and for major Csp from E. coli. Cs$\mathrm{pA}^{\text {. }}$ Generally, maximum positive band at $200 \mathrm{~nm}$ as well as minimum negative band at $225 \mathrm{num}$ are the characteristics of antiparallel $\beta$-sheet strnicture. Csp exhibits an unusual far UV$\mathrm{CD}$ spectrum for a predominantly $\beta$-sheet protein. It is believed that the far-UV CD spectrum of Csp is due to the $\beta$-structure rich in aromatic amino acid residues. preventing a detailed analy sis of the secondary structure. CpCsp have seven aromatic residues (four Phe. one Trp and two Tyr). There is a tendency for the aromatic side chains such as Tyг and Trp in protein to

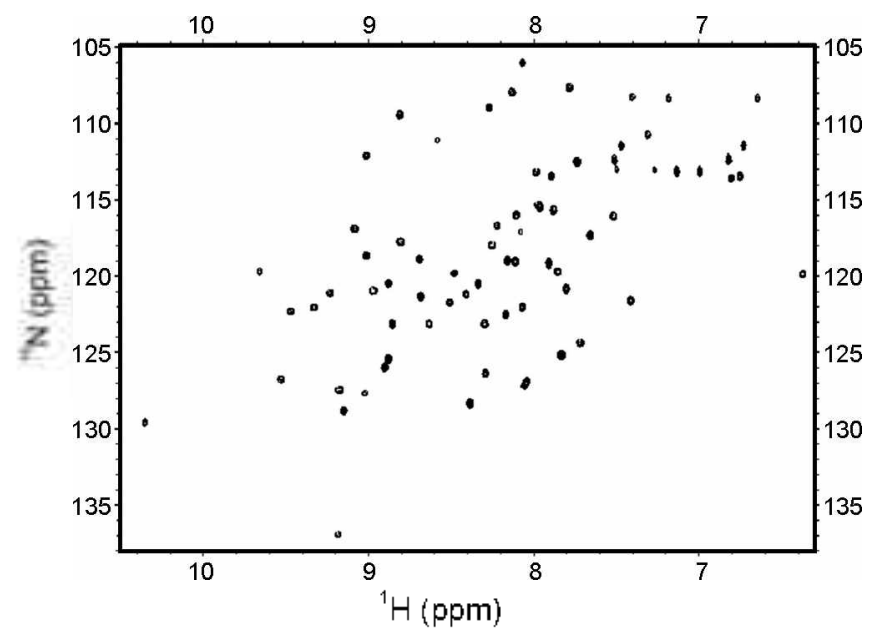

Figure 5. $\left[{ }^{1} \mathrm{H}^{1}{ }^{15} \mathrm{~N}\right] \mathrm{HSQC}$ spectrum of CpCsp in $50 \mathrm{mM}$ potassium phosphate buffer at $25^{\circ} \mathrm{C}$.

give positive CD features in the between 215 and $230 \mathrm{~mm}^{28}$ Therefore. weak positive ellipticity between 215 and $230 \mathrm{~nm}$ has been attributed to the $\beta$-sheet structure as well as these side chains of aromatic residues positioned on the surface of $\beta$ sheets ${ }^{2-33}$ and the CD maximum between 195 and $200 \mathrm{~nm}$ originates from the antiparallel $\beta$-sheet structure, ${ }^{2,24}$ Therefore, $C D$ spectra of $\mathrm{CpCsp}$ adopted an antiparallel $\beta$-sheet conformation similar to other Csps.

NMR experiment. As shown in Figure 5. the HSQC spectrum confirmed the high purity of ${ }^{15} \mathrm{~N}$-labeled CpCsp by showing 60 nicely resolved peaks, which correspond to the number of the residues in CpCsp. except proline. 6 peaks were not shown because of the spectral overlapping. There were six sets of peaks from the side chain of Gln and Asn. One peak from the side chain of Trp appeared to $10.5 \mathrm{ppm}$. Although the ${ }^{\mathrm{l}} \mathrm{H}$ NMR spectrum of CpCsp in $50 \mathrm{mM}$ potassium phosphate buffer was difficult to analyze because of the severe overlapping. the amide resonances were dispersed in the ${ }^{1} \mathrm{H} \cdot{ }^{15} \mathrm{~N}$ HSQC spectra.

\section{Conclusion}

Cold shock proteins have been found in many bacteria, including hyperthemophilic. themnophilic. mesophilic. and psțchrophilic species. The three-dinemsional structures of a number of bacterial Csps have been solved by NMR and X-ray. Csp from psyclurophilic bacteria has not been studied much yet. In order to understand the mechanism of cold adaptation of psychrophilic bacteria. we decided to study structure of C sp from psychrophilic bacteria, Colwellia psichrervthraea. We optimized the overexpression and purification conditions such as temperature, agitation velocity (rpm). and purification methods. Each condition for CpCsp was optimized and CpCsp was successfully expressed and purified. According to the CD spectra. CpCsp adopted an antiparallel $\beta$-sheet conformation sinuilar to other Csps. However CpCsp have unusual CD band at farUV region because of seven aromatic residues. Isotope label$\operatorname{ing}\left({ }^{15} \mathrm{~N}\right)$ was also successfully performed for the studies of the structure and dynamics of the CpCsp in potassium phosphate buffer. Result of CD spectrum showed that CpCsp have an 
antiparallel $\beta$-sheet structure and NMR spectrum showed that CpCsp have excellent dispersion of the resonances. Therefore. CpCsp was fold properly in potassium phosphate buffer. In conclusion, the expression and purification protocols for the CpCsp described in this paper could be applied to high-level expression and purification of various kinds of psychrophilic bacterial Csp. Further stnıctural studies on CpCsp will be performed.

Acknowledgments. This research was supported by Basic Science Research Program through the National Research Foundation of Korea (NRF) funded by the Ministry of Education. Science and Technology $(2008-C 00+20)$ and by the Korea Polar Research Institute (KOPRI PE09070). Chang-Hun Moon and Ki-Woong Jeong are supported. in part. by the second BK21 (MOE).

\section{References}

1. Nuray, N.; Ferhan, E. Turk. J. Med. Sci. 2001, 31, 283.

2. Wençing, F.; Roberto, T.; Diane, E. Z:; Masayori, I.: Gaetano, T. M. Biochemistry 1998, 37, 10881 .

3. Heather, A. T.; Pamela, G. T.; Masayori, I. BioEssav 20.1 1998, 20,49 .

4. Thomas, S.; Peter, L. G.: Dieter, P.; Saufung, M.; Franz, X. S.; Mohamed, A. M. J. Biol. Chent 1999, 274, 3407.

5. Perl, D; Welker, C.: Schindler, T.; Schroder, K.; Marahiel, M. A.: Jaenicke, R.: Schmid, F. X. Nat. Strtict. Biol. 1998, 5, 229.

6. Lim, T.; Thomas, T; Cavicchioli, R.J.A fol. Biol. 2000, $297,553$.

7. Phadtare, S.; Inouye, M.; Severinov, K. J. Biol. Chem. 2002, 277, 7239.

8. Phadtare, S.: Severinov, K. J. Bacteriol 2005, 187, 6584.

9. Horn, G.; Hofweber, R; Kremer, W; Kalbizer, H. R. Cell Mol. Life Sci. 2007, 64, 1457.

10. Katherin, L. R.; Hector, M. R.: Brian, J. H.; Lydia, M. G. Protein Sci. 1998, 7, 470 .

11. Max, K. E.: Zeeb, M: Bienert, R.; Balbach, T.; Heinemann, U. FEBS J. 2007, 27t, 1265 .

12. Schnuchel, A.: Wiltscheck, R.: Ceisch, M.: Herrler, M.; Willimskv; G.; Graumanm, P.; Marahiel, M. A.; Holak, T. A. Kature 1993,
364,169

13. Schindelin, H.; Marahiel, M. A.; Heinemann, U. Natme 1993. $36 \% 164$.

14. Newkirk, K; Feng, W; Jiang, W; Tejero, R.; Emerson, S. D.; Inouve, M.; Montelione, G. T. Proc. Natl. Acad. Sci. LSA 1994 , 91,5114 .

15. Schindelin, H.: Tiang. W.: Inouye. M.: Heinemann. U. Proc. Natl. Acad. Sci. LS.1 1994, 91, 5119.

16. Melody, S. C.: Andrew, C. Charles, S. C. Peter, C; H, W. D: Keiron, P. P. F.: Ian, A. T.; Barbara, A. M.; Alison, E. M.: Lloyd, S. P: Karin, R:; Alex, D. R. Comp. Funct. Genom. 2004, 5 , 230 .

17. Teong, K.-W.; Lee, T.-Y; Kang, D. I.; Lee, J.-U.; Hwang, Y.-S.; Kim, Y. Bull. Kowan Chent. Soc. 2008, 29,7.

18. Woonghee, K.: Sun-Hee, B.; Dong-Il, K.; Hang-Cheol, S.; Yangmee, K. Bull. Korean Chem. Soc. 2008, 29, 11.

19. Delaglio, F.: Grzesiak, S.; Vuister, G.; Zhu, G.: Pfeifer, I.; Bax, A. J. Biontol. $M \mathbb{R} R$ 1995, 6, 277

20. Goddard, T. D.; Kneller, D. G. SPARKY3, University of Califonia, San Francisco. 2003

21. Schindelin, H.: Henler, M.; Willinsky, G.; Marahiel, M. A.; Heinemann, U. Proteins: Stuct. Funct. Genet. 1992, 14, 120.

22. Schmitt, E.; Guillon, J. M.; Meinnel, T.; Mechulam, Y.; Dardel, F. Blanquet, S. Biochimie 1996, 78, 543.

23. Schindler, T.: Schmid, F. X. Biochemistn 1996, 35, 16833

24. Welker, C.; Bolum, G.; Schurig, H.; Taenicke, R. Protein Sci. 1999. 8. 394.

25. Zaremba, S. M: Gregoret, L. M. J. 1hol. Biol. 1999, $291,463$.

26. Hillier, B. J:; Rodriguez, H. M.; Gregoret, L. M. Fold. Des. 1998. 3.87.

27. Makhatadze, G. I.; Loladze, V. V; Gribenko, A. V; Lopez, M. M. J. Mol. Biol. 2004, $336,929$.

28. Berova, N.: Nakanishi, K.; Woody, R. W. Cincular Dichroism; Wiley-VCH: 2000: pp 612-614

29. Woody, R. W. Biopolymens 1978, 17, 1451 .

30. Chakrabartty, A.; Kortemme, T; Padmanabhan, S.; Baldwin, R. L. Biochemist $1993,32,5560$.

31. Vuilleunier, S.: Sancho, J.: Loewenthal, R.: Fersht, A. R. Biochemistm 1993, 32, 10303

32. Sreerama, N.; Manning, M. C.; Powers, M. E.; Zhang, J. X.; Goldenberg, D. P.; Woodv, R. W. Biochemistw 1999, 38, 10814 .

33. Sreeama, N.; Venyaminov, S. Y.; Woody, R. W. Protein Sci. 1999. 8. 370 .

34. Perczel, A.; Park, K; Fasman, G. D. Proteins: Strztct. Futct. Genet. 1992, 13,57 